\title{
IMPACT OF INSULIN PRODUCING STEM CELLS DERIVED FROM HUMAN BONE MARROW ON SOME DIABETIC COMPLICATIONS
}

\author{
Maha M. Azzam ${ }^{1}$, Mahmoud M. Gabr ${ }^{2}$, Nabil Abuheakal ${ }^{1}$, Mohamed A. Ghoneim ${ }^{2}$
}

Dept. of physiology, Faculty of Veterinary Medicine ${ }^{1}$, Urology and Nephrology Center ${ }^{2}$, Mansoura University

\begin{abstract}
Stem cells were derived from adult human bone marrow. After differentiation cells were encapsulated in the rectus abdominus sheath of diabetic dogs. Eighteen mongrel dogs were divided into three groups: normal non-diabetic group (6), diabetic untreated group (6), and treated group (6). Blood glucose levels was improved to be like normal range in diabetic dogs treated with stem cells. Lipid profile including triacylglycerol, HDL-C, LDL-C and cholesterol levels were significantly higher in diabetic untreated dogs and showed a significantly lowered levels in stem cells treated dogs than that in diabetic dogs and become nearly to normal dogs. ALT activities of diabetic dogs with treatment slightly improved than non- diabetic and diabetic untreated groups while AST activities returned to be as in normal group. Creatinine levels of untreated diabetic dogs was significantly higher than those of treated diabetic dogs and improved to be as in normal dogs. In this study, we successfully induced the differentiation of MSCs into functional insulin producing cells (IPCs) by transplanting IPCs into chemically induced diabetic dogs, it was found that IPCs were capable to improve blood glucose levels and so decrease the lipid profile, kidney function and liver function.

Keywords: Dog, Hyperlipidemia, Lipid profiles, liver function, Kidney function, stem cells, diabetes mellitus
\end{abstract}

\section{INTRODUCTION}

Diabetes mellitus is the most common endocrine disorder in the worldwide, it hits more than 285 million individuals. By 2030 it was expected that the number will grow to be 438 millions, corresponding to $7.8 \%$ of the adult population. Moreover diabetic deaths increased in low income nations as it is more than $80 \%$ (Tse et al., 2015). Increased blood sugar, decreased fibrinolytic, increased blood pressure, dyslipidemia, severe atherosclerosis, and increased platelet aggregation are the most risk factors for diabetes mellitus (Rajalakshmi et al., 2009). Moreover, this disease cause complications such as cardiac disease, stroke, kidney failure, loss of vision and damage of nerve (Steppan et al., 2001).

From the oldest agents used for hyperglycemia is insulin as it is the only agent that occurs naturally in humans with no upper dose limit. The risks of using insulin therapy is gain of weight (as all of the agents used for hyperglycemia, except metformin), hypoglycemia, and in very rare cases, allergic and cutaneous reactions (Nathan, 2002). Transplantation of Pancreatic islet is a viable and attractive option for the treatment of (T1DM) (Bruni et al., 2014; Rekittke et al., 2016). Using pig islets as donors for transplantion instead of human xenogenic 
transplantation due to a shortage of human donors (Zhu et al., 2015). Long and excessive immunosuppressive drugs has disadvantages on recipients such as opportunistic infection, malnutrition, neuritis, and intense morbidity and islet toxicity are the mainstay of immune modulatory remedies now. Immunosuppressive drugs long life using problems have to be controlled first and the paucity of donor tissue. As new sources of human $\beta$-cells are developed (e.g., stem cell-derived tissue), using semi permeable device protect pateints using immunosuppression and risk of tumorigenicity (Lee et al., 2009).

Using of Pancreas or islet transplantation give a solution for insulin independence, but has some problems due to its radical complications and insufficiency of organ donors, using insulin-secreting cells derived from MSCs is a hope for treatment (Vija et al., 2009). Mesenchymal stem cells (MSCs) was able for renewal and differentiation into various lineages including insulin producing cells (Romanov et al., 2003).

In this study, we induced Type 2 diabetes model by using alloxan and STZ in dogs. Subsequently the ability of MSCs to ameliorate some diabetic complications was tested

\section{MATERIAL AND METHODS}

\section{I- Human Bone Marrow Aspirate}

This study was approved by ethical committee of the Mansoura University. Three diabetic type 2 consenting donors bone marrow was aspirated from their iliac crests in heparin.

\section{II- Isolation and Expansion of HBM-MSCs}

The BMAs were diluted 1 : 1 with minimum essential medium Eagle Alpha modification ( $\alpha$-MEM, Sigma-Aldrich, St.
Louis, Missouri, USA), using (Ficoll-Paque, $1.077 \mathrm{~g} / \mathrm{mL}$ ) (Pharmacia, Uppsala, Sweden) thereafter centrifugation for about 20 minutes at $600 \mathrm{~g}$. After that, collection of cells from $\alpha-$ MEM /Ficoll interface was performed thereafter, cells were washed twice in phosphate buffer saline (PBS), and then resuspended in $10 \mathrm{~mL}$ of complete $\alpha$-MEM low glucose provided with fetal bovine serum $10 \%$ (Hyclone, Logan, UT, USA), 100U/mL penicillin, and $100 \mathrm{U} / \mathrm{mL}$ streptomycin (SigmaAldrich). Each $1 \mathrm{~mL}$ contain $\sim 1.5 \times 10^{6}$ nucleated cells. The collected cells were cultured at density of $5 \times 10^{5}$ cells $/ \mathrm{mL}$ using complete $\alpha$-MEM at a density of $(10 \mathrm{~mL}$ in 25 $\mathrm{cm}^{2}$ tissue culture flasks) and incubated at $37^{\circ} \mathrm{C}$ in $5 \% \mathrm{CO} 2$ incubator. The nonadherent cells were discarded after 3 days while the remaining adherent MSCs remained until reach $80 \%$ confluence to be subcultured using trypsin by resuspended the cells with complete $\alpha$ MEM and replated at a ratio of $1: 2$ and cultured for additional eight days, as to attain $80 \%$ confluence. For second passage the same steps done, then fibroblast-like cells appearance was found.

\section{III- Differentiation of HBM-MSCs into insulin producing Cells}

At density of $1 \times 10^{5}$ cells $/ \mathrm{mL}$ in passage three. Cells from each donor were induced to form IPCs using two stages Protocol according Tayaramma et al. method (Tayaramma et al., 2006). First stage using serum free DMEM contains Trichostatin-A (TSA) with concentration $55 \mathrm{nM}$ (Sigma-Aldrich) for three days. Second stage using high glucose $(25 \mathrm{mM})$ medium DMEM:DMEM/F12 (1:1) (SigmaAldrich) provided by fetal bovine serum 10\% and 10nM glucagon-like peptide-1 (GLP-1, Sigma-Aldrich) for seven days. 


\section{IV- Phenotyping}

At passage 3, trypsinization of cells, then centrifugation at $300 \mathrm{~g}$ for 8 minutes. Then cells were resuspended in PBS at a concentration of $1 \times 10^{6}$ cells $/ \mathrm{ml} .100 \mu \mathrm{L}$ aliquots were labeled (30mins) with antibodies against CD14, CD45 (FITC) or CD73, CD34 phycoerythrin (PE) (Becton-Dickinson, USA), or CD105 PE or CD90 (FITC) (Becton-Dickinson, USA), washed with $1 \mathrm{~mL}$ of stain buffer (BD Pharmingen, USA), and BioMed Research International 3 resuspended in $500 \mu \mathrm{L}$ of stain buffer. The labeled cells were analyzed using an argon ion laser with a wave length of 488 nm (FACS Calibur, Becton-Dickinson, USA). A total of 10000 events were obtained and analyzed with the Cell Quest software program (Becton-Dickinson, USA). Control staining with appropriate isotype-matched monoclonal antibodies was included.

\section{V- Induction of diabetes}

A solitary dose of an alloxan $(40 \mathrm{mg} / \mathrm{kg})$ (Sigma-Aldrich)/ streptozotocin $\quad(35 \mathrm{mg} / \mathrm{kg})$ (Sigma-Aldrich) was given intravenously (IV). Both drugs were initially prepared aseptically as solutions in citric acid buffer $\mathrm{pH} 4.5$ (Anderson et al., 1993). 48 hours prior alloxan-STZ administration, dogs with nonfasting glucose more than $300 \mathrm{mg} / \mathrm{dl}$ were approved as diabetic. The dogs were divided into 3 groups as follows: normal group: 6 dogs, diabetic group: 6 dogs without treatment and treated group with stem cells: 6 diabetic dogs received ( 5 million $/ \mathrm{kg}$ body weight) MSCs for each dog.

At different times (6,12,18 months) after implantation of MSCs, blood samples were collected, for detection of glucose, total cholesterol (TC), TAG, HDL-C, LDL-C, AST, ALT, and Creatinine levels and activities.

\section{VI- Assessment of biochemical parameters}

Blood sugar was detected by using Glucometer strips (Accu-Check performa, Roche Diagnostics, Mannheim, Germany) and body weight was determined, weekly. Determination of Serum total cholesterol according to Expert Panel method (Expert Panel on Detection, 2001), Serum TAG concentration was determined using the method which described by Willard and Tvedten (Willard and Tvedten, 2011), The serum (LDL-C) concentration was calculated from the total cholesterol concentration according to Friedewald WT et al. (Friedewald et al., 1972). The serum HDL-C levels were measured by colormetric kit according to Finley PR et. al. method (Finley et al., 1978) by using HDL-C kit which bought from SPINREACT, S.A. Ctra, Santa Coloma, Espain. According to Reitman et. al. serum alanine aminotransferase (ALT) and Aspartate aminotransferase (AST) activities were determined (Reitman and Frankel, 1957) using a commercially available assay kit (Egyptian American Company for Laboratory Services, Egypt), Using a modified rate Jaffe method serum creatinine was estimated as described by jaffe (Jaffé, 1886) using kits obtained from (Beckman, USA), following the instructions manufacture.

\section{VII- Statistical analysis}

The difference of biochemical analysis between three groups and the relation between them was performed using Statistical Package for the Social Sciences (SPSS Statistics 17.0) (SPSS, Chicago, IL, USA). The comparison of the change between different groups was determined using non parametric spearman, Anova. The significance was considered less than 0.05 (Chinna et al., 2012). 


\section{RESULTS}

\section{Morphology and Phenotype}

The cultured bone marrow cells at the final stage of expansion was arranged in monolayers as homogenous fibroblastic spindle shape, fig (1). There was no apparent differences in the rate of duplication of cells derived from the three donors. Flow cytometric analysis showed that these cells possess elevated levels of CD90, CD73, and CD105 while the levels of CD45, CD14, and CD34, this indicate that these cells are pure MSCs.

Effect of differentiated MSCs on biochemical parameters was summarized in table (1):

\section{1- Effect of MSCs on blood glucose}

The blood glucose in diabetic group increased more than normal group and returned to normal after transplantation of MSCs $\mathrm{p}>0.05$. Fig 2

\section{2-Effect of MSCs on liver function tests}

The mean blood Alanine aminotransferase ALT\& AST activities are strongly significant increased in diabetic group comparing to normal group transplantation and in treated group AST activity decline again to be as in normal group while ALT activity slightly declined but didn't reach normal group. Fig 3 $(a, b)$

\section{3-Effect of MSCs on serum lipid profile}

The values of HDL-C, LDL-C, cholesterol and TAG were significantly increased in diabetic group more than normal group and improved after MSCs transplantation (treated group). Fig 4 (a,b,c,d)

\section{4-Effect of MSCs on kidney function}

The results showed that, the serum creatinine was strongly significant increased in diabetic dogs compared to normal group, $(\mathrm{P}>0.05)$. Treated dogs showed significant decrease in serum creatinine and became nearly similar to that in normal group. Fig (5).

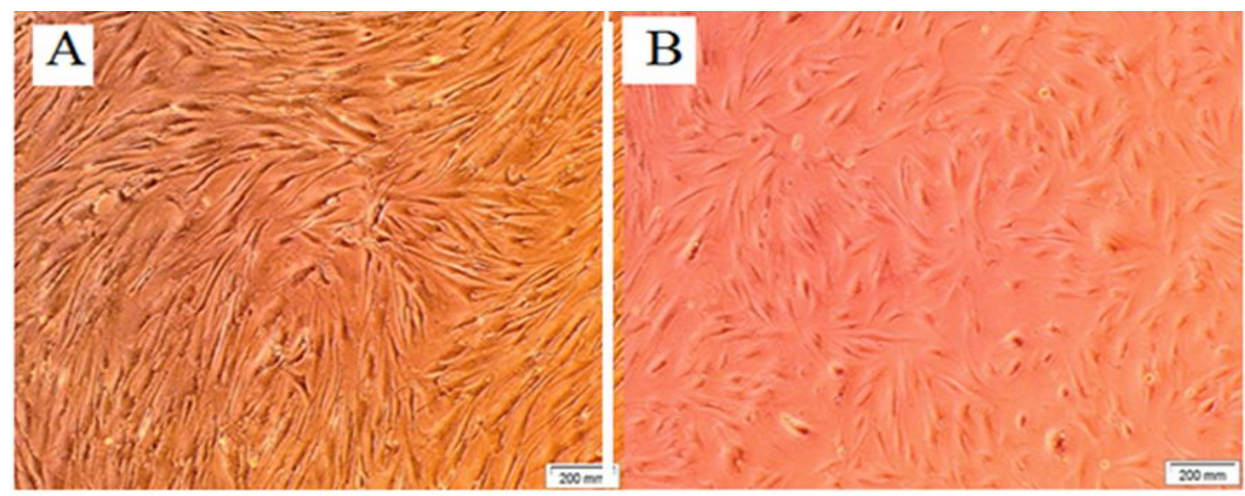

Fig (1): Histogram demonstrated morphological changes of Mesenchymal stem cells during differentiation (A) Undifferentiated MSCs after isolation (X 200), (B) Differentiated MSCS after 10 days by Trichostatin-A and GLP-1 protocol (X 60). 


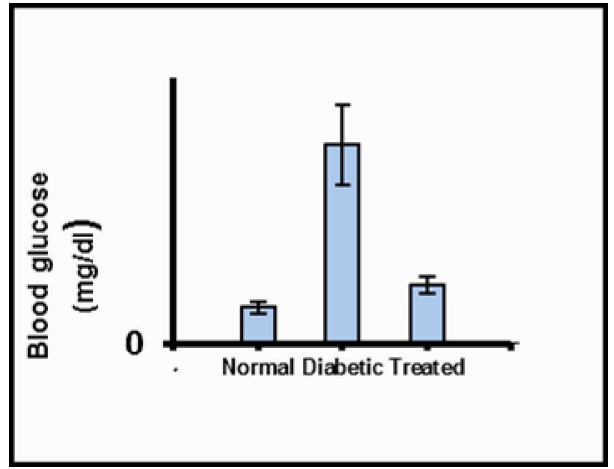

Fig (2): A Diagram shows changes in serum blood glucose among 3 studied groups. As serum blood glucose decrease in treated group to become nearly equal normal group.
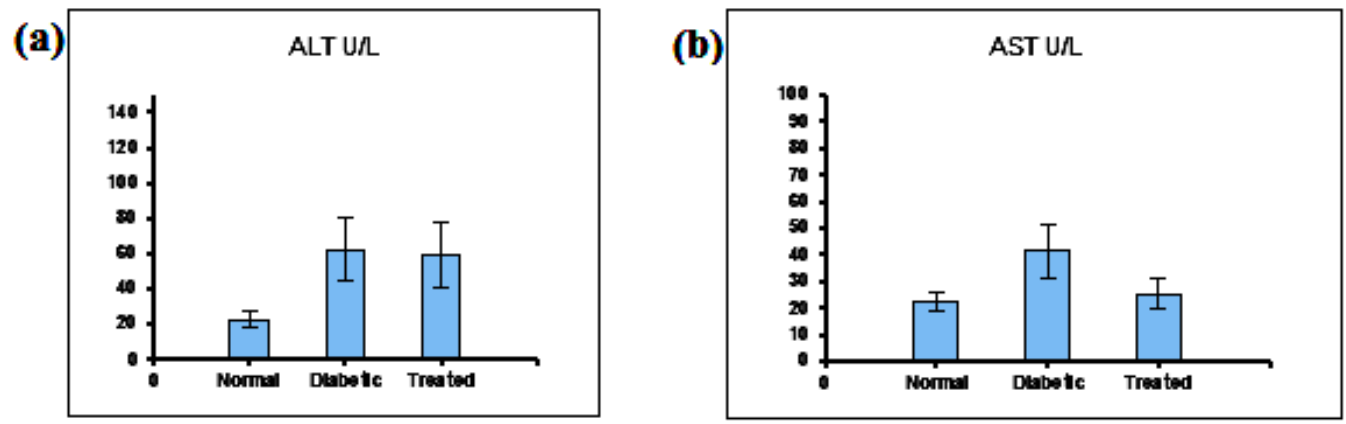

Fig (3): Effect of MSCs on liver function (a) ALT and (b) AST

(a)

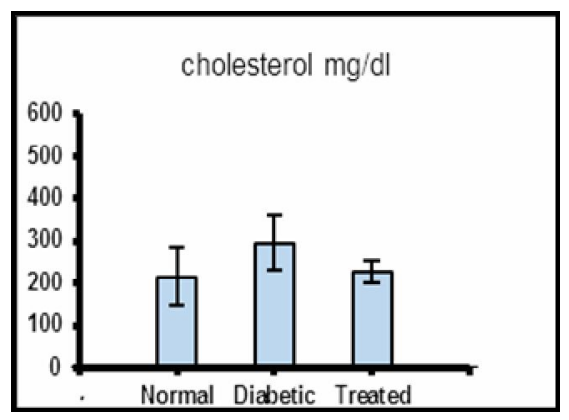

(c)

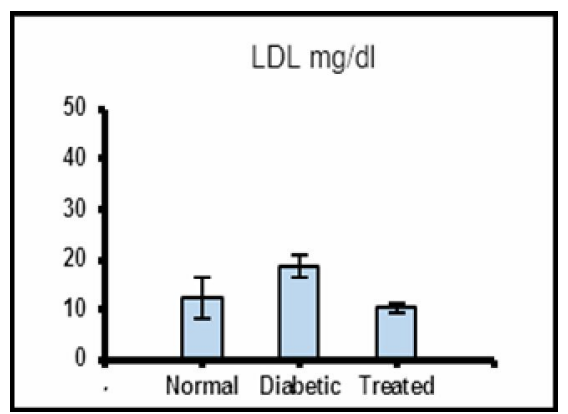

(b)

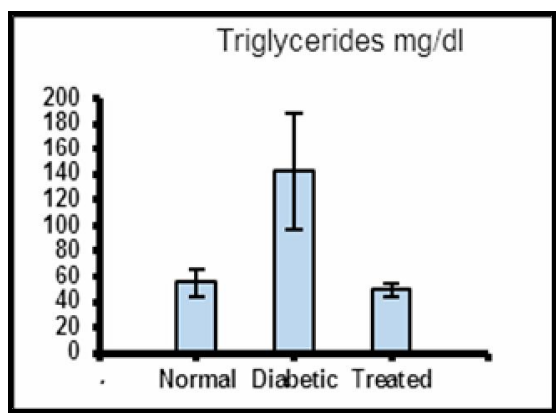

(d)

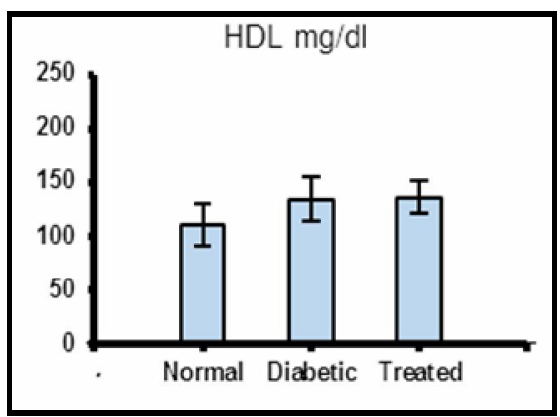

Fig (4): Effect of MSCS on (a) cholesterol, (b) TAG, (c) HDL-C and (d) LDL-C. 


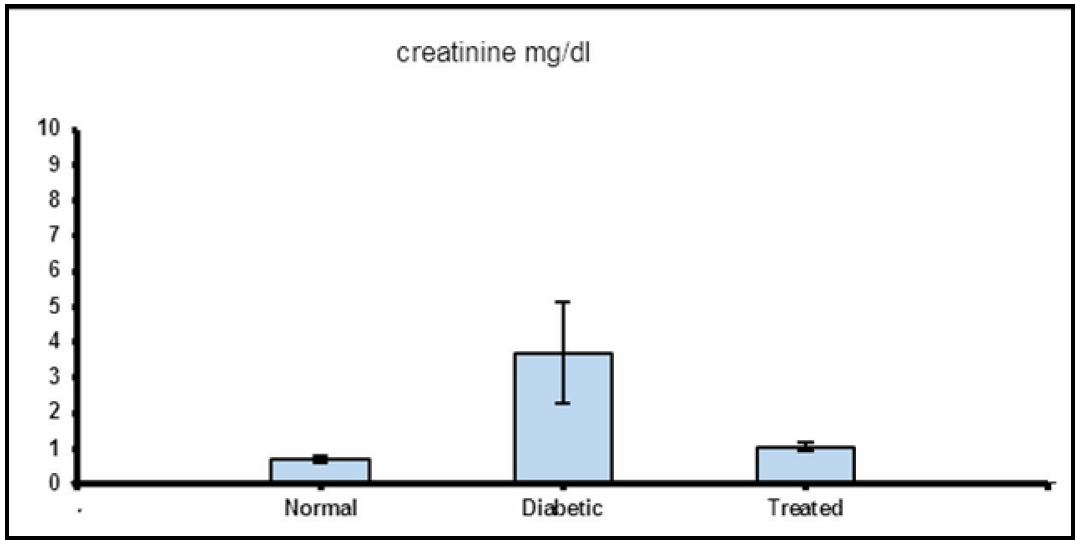

Fig (5): Effect of MSCs on creatinine level

Table (1):Serum glucose, AST, ALT, cholesterol, Lipid profile, Creatinine.

\begin{tabular}{|l|c|c|c|}
\hline & Normal group & Diabetic group & Treated group \\
\hline Serum glucose (mg/dl) level & $82.50 \pm 28.63$ & $449.00 \pm 222.91^{*}$ & $132.50 \pm 43.98^{*}$ \\
\hline AST(U/L) activity & $22.16 \pm 8.37$ & $41.50 \pm 24.36$ & $25.50 \pm 13.63$ \\
\hline ALT(U/L) activity & $22.00 \pm 10.48$ & $62.50 \pm 43.39$ & $59.33 \pm 45.00$ \\
\hline TAG(mg/dl) activity & $55.16 \pm 26.17$ & $142.33 \pm 112.16^{*}$ & $49.33 \pm 12.84^{*}$ \\
\hline LDL-C(mg/dl) level & $12.44 \pm 10.13$ & $18.81 \pm 5.52$ & $10.25 \pm 2.71$ \\
\hline HDL-C(mg/dl) level & $110.66 \pm 19.65$ & $133.66 \pm 20.42^{*}$ & $136.16 \pm 15.56^{*}$ \\
\hline Cholesterol(mg/dl) level & $215.66 \pm 68.22$ & $294.66 \pm 64.57^{*}$ & $228.66 \pm 26.33^{*}$ \\
\hline Creatinine(mg/dl) level & $0.71 \pm 0.20$ & $3.70 \pm 3.47^{*}$ & $1.06 \pm 0.25^{*}$ \\
\hline
\end{tabular}

Results are expressed as mean \pm SE, values were significantly different at $\mathrm{p} \leq 0.05$.

\section{DISCUSSION}

Diabetes mellitus is characterized by increased levels of blood glucose due to deficiencies in insulin secretion, action or both which cause impairment in metabolic functions of carbohydrates, proteins, and lipids (Jiang et al., 2011).

Synthetic drugs used in diabetes treatment have many disadvantages as low blood glucose at higher dose administration, low oral bioavailability due to degradation in stomach, inactivation and digestion by proteolytic enzymes in the luminal cavity, and poor permeability across the intestinal epithelium make it necessary to find other alternatives (Mohini et al., 2012) Lately, it was found that transplantation of islet can retrieve glucose in type 1 diabetes to it's normal range, however there is two obstacles for this therapy which are the chronic use of immunosuppressive drugs to prevent rejection of allogenic graft and supply tissue of human islets (Lakey et al., 2003; Shapiro et al., 2000). As a replacement for transplantation of islets stem cells were used as it has the ability to self-renewal, differentiate and insulin production as a renewable source. 
According to these finding, we efficiently succeeded to direct MSCs into insulin producing cells.

Chronic mild increase of the transaminases was repeatedly in type 2 diabetic peoples. (Ohlson et al., 1988) explained the risk for ALT elevation in type 2 diabetes in non-diabetic Swedish male and it's not depend on the distribution of body fat, plasma glucose, obesity, concentration of lipid, AST and bilirubin and family history of diabetes. In this study, the diabetic dogs have elevated activities of AST and ALT and these results were agreed with other studies which compared type 2 diabetes people with non diabetic peoples for the incidence of abnormalities in liver function (Harris, 2005). It is safe to use antidiabetic agents when transaminases are elevated as it has effect on transaminases by lowering it. Our result confirmed the previous data which showed that treating diabetes with MSCs restored the activities of ALT and AST (Tsai et al., 2009).

In the present, after inducing diabetes in dog serum creatinine was significantly increased and return to normal after MSCs transplantation. Several investigators showed that diabetic animals has hypertriglyceridemia, hypercholestermia with increased HDL and abnormalities in lipoprotein levels which was agreed with our results (Mathe, 1995; Wasan et al., 1998) Increase mobilization from adipose tissue leads to increased plasma free fatty acids and this related to type 2 diabetes and causes elevated levels of serum lipids as insulin inhibit hormone sensitive lipase (AlShamaony et al., 1994).

\section{REFERENCES}

Al-Shamaony L., Al-Khazraji S.M., and Twaij H.A. (1994). Hypoglycaemic effect of artemisia herba alba. Ii. Effect of a valuable extract on some blood parameters in diabetic animals. Journal of Ethnopharmacology, 43(3), 167-171.

Anderson H., Stitt A., Gardiner T., Lloyd S., and Archer D. (1993). Induction of alloxan/streptozotocin diabetes in dogs: A revised experimental technique. Laboratory animals, 27(3), 281-285.

Bruni A., Gala-Lopez B., Pepper A.R., Abualhassan N.S., and Shapiro A. (2014). Islet cell transplantation for the treatment of type 1 diabetes: Recent advances and future challenges. Diabetes Metab Syndr Obes, 7, 211223.

Chinna K., Karuthan K., and Choo W.Y. (2012). Statistical analysis using spss: Pearson Malaysia.

Expert Panel on Detection E. (2001). Executive summary of the third report of the national cholesterol education program (ncep) expert panel on detection, evaluation, and treatment of high blood cholesterol in adults (adult treatment panel iii). Jama, 285(19), 2486.

Finley P.R., Schifman R.B., Williams R.J., and Lichti D.A. (1978). Cholesterol in high-density lipoprotein: Use of $\mathrm{mg} 2+/$ dextran sulfate in its enzymic measurement. Clinical chemistry, 24(6), 931-933.

Friedewald W.T., Levy R.I., and Fredrickson D.S. (1972). Estimation of the concentration of low-density lipoprotein cholesterol in plasma, without use of the preparative 
ultracentrifuge. Clinical chemistry, 18(6), 499-502.

Harris E.H. (2005). Elevated liver function tests in type 2 diabetes. Clinical diabetes, 23(3), 115-119.

Jaffé M. (1886). Ueber den niederschlag, welchen pikrinsäure in normalem harn erzeugt und über eine neue reaction des kreatinins. Zeitschrift für physiologische Chemie, 10(5), 391-400.

Jiang R., Han Z., Zhuo G., Qu X., Li X., Wang X., Shao Y., Yang S., and Han Z.C. (2011). Transplantation of placenta-derived mesenchymal stem cells in type 2 diabetes: A pilot study. Frontiers of medicine, 5(1), 94-100.

Lakey J.R., Burridge P.W., and Shapiro A. (2003). Technical aspects of islet preparation and transplantation. Transplant international, 16(9), 613632.

Lee S.-H., Hao E., Savinov A.Y., Geron I., Strongin A.Y., and Itkin-Ansari P. (2009). Human $\beta$-cell precursors mature into functional insulin-producing cells in an immunoisolation device: Implications for diabetes cell therapies. Transplantation, 87(7), 983.

Mathe D. (1995). Dyslipidemia and diabetes: Animal models. Diabete \& metabolisme, 21(2), 106-111.

Mohini P., Subhash P., Manohar P., Abhijit T., and Vijay N. (2012). Effect of thespesone-vanadium complex in alloxan induced diabetic rats. African Journal of Pharmacy and Pharmacology, 6(10), 692-697.

Nathan D.M. (2002). Initial management of glycemia in type 2 diabetes mellitus. New England Journal of Medicine, 347(17), 1342-1349.
Ohlson L.-O., Larsson B., Björntorp P., Eriksson H., Svärdsudd K., Welin L., Tibblin G., and Wilhelmsen L. (1988). Risk factors for type 2 (noninsulin-dependent) diabetes mellitus. Thirteen and one-half years of followup of the participants in a study of swedish men born in 1913. Diabetologia, 31(11), 798-805.

Rajalakshmi M., Eliza J., Priya C.E., Nirmala A., and Daisy P. (2009). Anti-diabetic properties of tinospora cordifolia stem extracts on streptozotocin-induced diabetic rats. African Journal of Pharmacy and Pharmacology, 3(5), 171-180.

Reitman S., and Frankel S. (1957). A colorimetric method for the determination of serum glutamic oxalacetic and glutamic pyruvic transaminases. American journal of clinical pathology, 28(1), 56-63.

Rekittke N.E., Ang M., Rawat D., Khatri R., and Linn T. (2016). Regenerative therapy of type 1 diabetes mellitus: From pancreatic islet transplantation to mesenchymal stem cells. Stem cells international, 2016.

Romanov Y.A., Svintsitskaya V.A., and Smirnov V.N. (2003). Searching for alternative sources of postnatal human mesenchymal stem cells: Candidate mslike cells from umbilical cord. Stem cells, 21(1), 105-110.

Shapiro A.J., Lakey J.R., Ryan E.A., Korbutt G.S., Toth E., Warnock G.L., Kneteman N.M., and Rajotte R.V. (2000). Islet transplantation in seven patients with type 1 diabetes mellitus using a glucocorticoid-free immunosuppressive regimen. New England Journal of Medicine, 343(4), 230-238. 
Steppan C.M., Bailey S.T., Bhat S., Brown E.J., Banerjee R.R., Wright C.M., Patel H.R., Ahima R.S., and Lazar M.A. (2001). The hormone resistin links obesity to diabetes. Nature, 409(6818), 307-312.

Tayaramma T., Ma B., Rohde M., and Mayer H. (2006). Chromatinremodeling factors allow differentiation of bone marrow cells into insulinproducing cells. Stem cells, 24(12), 2858-2867.

Tsai P.C., Fu T.W., Chen Y.M.A., Ko T.L., Chen T.H., Shih Y.H., Hung S.C., and Fu Y.S. (2009). The therapeutic potential of human umbilical mesenchymal stem cells from wharton's jelly in the treatment of rat liver fibrosis. Liver transplantation, 15(5), 484-495.

Tse H.M., Kozlovskaya V., Kharlampieva E., and Hunter C.S. (2015). Minireview: Directed differentiation and encapsulation of islet $\beta$-cellsrecent advances and future considerations.

Molecular

Endocrinology, 29(10), 1388-1399.
Vija L., Farge D., Gautier J.-F., Vexiau P., Dumitrache C., Bourgarit A., Verrecchia F., and Larghero $J$. (2009). Mesenchymal stem cells: Stem cell therapy perspectives for type 1 diabetes. Diabetes \& metabolism, 35(2), 85-93.

Wasan K.M., Ng S.P., Wong W., and Rodrigues B.B. (1998). Streptozotocinand alloxan-induced diabetes modifies total plasma and lipoprotein lipid concentration and composition without altering cholesteryl ester transfer activity. Basic \& Clinical Pharmacology \& Toxicology, 83(4), 169-175.

Willard M.D., and Tvedten H. (2011). Small animal clinical diagnosis by laboratory methods: Elsevier Health Sciences.

Zhu H.-T., Lu L., Liu X.-Y., Yu L., Lyu Y., and Wang B. (2015). Treatment of diabetes with encapsulated pig islets: An update on current developments. Journal of Zhejiang University Science $B, 16(5), 329-343$. 


\section{الملخص العربي \\ تأثير الخلايا الجذعية المنتجة للانسولين والمستخرجة من نخاع العظام في الانسان علي بعض مضاعفات مرض السكري}

مها محمد عزام- محمود محمد جبر - نبيل ابو هيكل - محمد احمد غنيي

مرض السكر، هو مرض مزمن ذو تأثير سلبي على الحيـاة الاجتماعية والاقتصادية، وفي جميع انواعه يؤثر

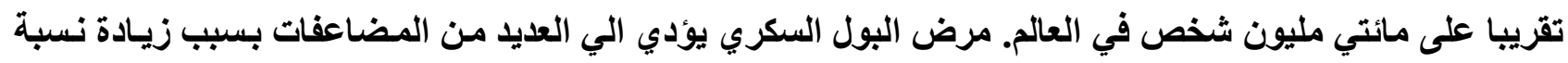

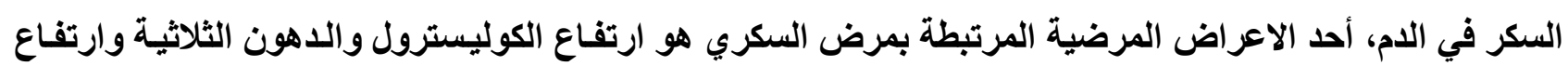

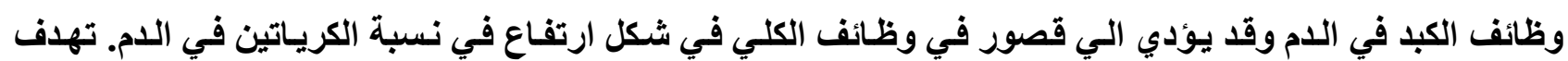

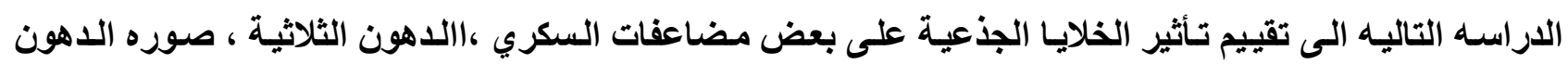

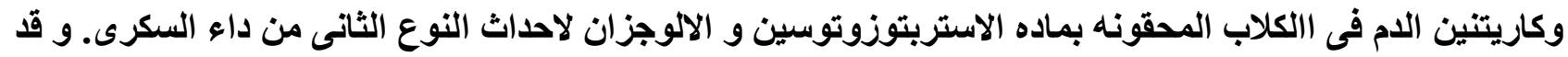
تم اجراء الاراسة على عدد ^1 من الكلاب المهجنه و التى تم تقسيمهم الى ثلاث مجموعات: المجموعة الاولى: غير مصابة بمرض السكري.

المجموعه الثانيه: يعانون من مرض السكري ولم يتم معالجتهم .

المجموعه الثالثه : يعانون من مرض السكري وتم معالجتهم بالخلايا جذعية

وقد اشارت النتائج الى ان

(1) مستوى الجلوكوز فى اللام زاد بشكل ملحوظ فى المجموعه الثانيـة مقارنها بالمجموعه الاولى كمـا اظهرت

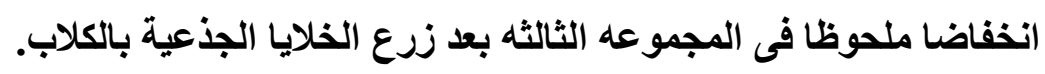

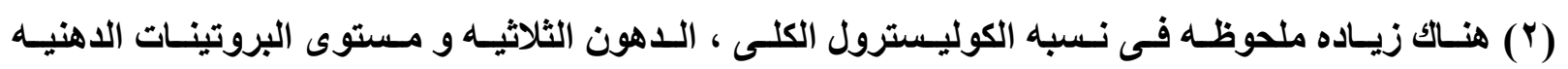

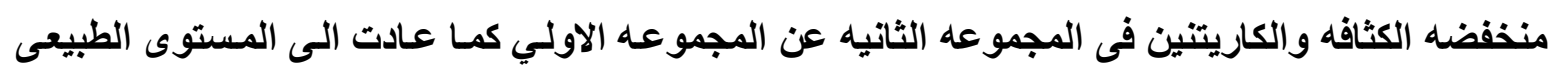
فى المجموعه الثالثة. ومسن هـذه الدراسـة نـستنتج ان الخلايـا الجذعيـة المنتجـة للانسسولين قـادرة علـي تحسين مسرض السكري وبعض مضاعفاته. 